\title{
A evolução cética da filosofia na ficção de Machado de Assis ao longo de quatro encontros na Rua do Ouvidor
}

\author{
The skeptical evolution of philosophy in Machado de Assis's \\ fiction over four meetings at Ouvidor street
}

José Raimundo Maia Neto

https://orcid.org/0000-0003-2868-3301 - E-mail: jrmaia@fafich.ufmg.br

\begin{abstract}
RESUMO
São analisados no artigo quatro encontros na Rua do Ouvidor do narrador ficcional e protagonista de quatro narrativas de Machado de Assis. As narrativas são examinadas diacronicamente de modo a mostrar a evolução de uma perspectiva cética ao longo da ficção machadiana. Cada encontro sinaliza uma etapa na construção dessa perspectiva. No Primeiro Encontro são apresentadas as condições prévias ao surgimento da perspectiva cética na segunda fase. Examine-se o conto Felicidade pelo Casamento publicado no início da primeira fase da obra do escritor, no qual a aparência se contrapõe à realidade, caracterizando uma perspectiva dogmática. No Segundo Encontro, destacado das Memórias Póstumas de Brás Cubas, romance que inicia a segunda fase e a perspectiva cética, a aparência penetra até o âmago da realidade, caracterizando uma perspectiva pascaliana. No Terceiro Encontro, flagrado no romance Dom Casmurro, a aparência obscurece a realidade, caracterizando uma perspectiva cética clássica. Enfim, no Quarto Encontro, presente no último romance de Machado, o Memorial de Aires, a aparência é o objeto e alvo último da percepção, caracterizando uma perspectiva cética-estética original machadiana. O artigo começa com uma apresentação da importância da Rua do Ouvidor na obra de Machado em geral.
\end{abstract}

Palavras-chave: Machado de Assis. Rio de Janeiro. Ceticismo. Pascal. Estética.

\section{ABSTRACT}

Four meetings of the narrator/protagonist on Ouvidor street (Rio de Janeiro city) in four Machado de Assis' stories are examined diachronically in order to show the evolution of a 
skeptical perspective in his fiction. Each meeting indicates a step in the construction of this perspective. The first meeting occurs in the short story Happiness through marriage, one of Machado's earliest ones. It exhibits the antecedent conditions to the development of the skeptical perspective along the second phase of Machado's literary production, namely, a dogmatic view opposing false appearance to true reality. The second meeting is extracted from The Posthumous Memoirs of Brás Cubas, the novel that marks the beginning of Machado's second and skeptical phase. The meeting shows the false appearances penetrating and corrupting true reality, characterizing a Pascalian perspective. In the third meeting, from Dom Casmurro, appearance obscures reality, characterizing a classic skeptical perspective. Finally, in the fourth meeting, pointed out in Machado's last novel, Counselor Ayres's Memorial, appearance is the object of perception, which no longer attempts to reach a hidden reality, characterizing an original Machadian aesthetic kind of skepticism. The article begins with general remarks about the relevance of Ouvidor street in Machado de Assis' work.

Keywords: Machado de Assis. Rio de Janeiro. Skepticism. Pascal. Aesthetics.

\section{A Rua do Ouvidor na obra de Machado de Assis}

Machado de Assis nasceu, viveu e morreu na cidade do Rio de Janeiro, de onde só saiu para ir uma rápida vez a Barbacena e duas vezes a Nova Friburgo para recuperação da saúde dele (na primeira vez) e da esposa (na segunda), esta última sem sucesso. Também ocasionalmente ia a Petrópolis, cidade que era em sua época, como sugere em uma crônica, um "prolon-

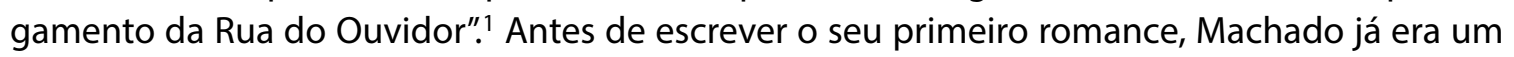
exímio cronista. Comenta, principalmente para os cariocas leitores dos jornais Diário do Rio de Janeiro, Semana llustrada, Gazeta de Notícias e outros, eventos ocorridos no exterior, no interior (a "província") e principalmente na própria cidade (a "corte"). A Rua do Ouvidor comparece com frequência na sua extensa produção de crônicas. Limito-me aqui a citar como ilustração a crônica que publicou em 8 de outubro de 1893 na Gazeta de Notícias por ocasião do falecimento do seu editor Jean-Baptiste Garnier. Já sob a República no final do século, a crônica atesta o início da decadência da rua com o deslocamento da elite rumo a zona sul da cidade (Laranjeiras, onde Machado residiu de 1884 até o final de sua vida, Flamengo e Botafogo). Através do seu finado amigo e editor, Machado expressa a nostalgia dos tempos áureos da Rua do Ouvidor, aquela que foi cenário dos seus romances e contos, de certa forma lamentando a nova configuração urbana da cidade, pois o cemitério aludido fica em Botafogo.

Segunda-feira desta semana, o livreiro Garnier saiu pela primeira vez de casa para ir a outra parte que não a livraria. Revertere ad locum tuum - está escrito no alto da porta do cemitério de S. João Batista. Não, murmurou ele talvez dentro do caixão mortuário, quando percebeu para onde o iam conduzindo, não é este o meu lugar; o meu lugar é na Rua do Ouvidor 71 [...\} Esta livraria é uma das últimas casas da Rua do Ouvidor; falo uma rua anterior e acabada. (OC, II, 653).

\footnotetext{
1 Em uma crônica de 22 de janeiro de 1893 sobre cidades do interior fluminense que pleiteavam se tornar a capital do estado do Rio de Janeiro, que passaria a ser somente capital da República, o cronista examina o pleito de Petrópolis, contra o qual pesava o fato de "não estar muito longe da Rua do Ouvidor" e convinha a mudança da capital "para outra cidade que não fique sendo um prolongamento da Rua do Ouvidor". Boa parte da elite da capital passava o verão ou parte dele na cidade serrana mais próxima do Rio com clima bem mais ameno. Nesta mesma crônica, declara: "sou puro carioca". ASSIS, Machado de. Obra completa. 3 vols. Rio de Janeiro: José Aguilar, 1959. Vol. III, p. 565. Doravante OC, seguida do volume em algarismos romanos e página em arábicos.
} 
O Rio de Janeiro presente na ficção machadiana é principalmente a corte do Segundo Reinado. Somente os três últimos romances são publicados já na República. O primeiro escrito sob a República, Dom Casmurro, é ambientado no Segundo Reinado e assinala a autoridade do Imperador. Bentinho fica fascinado pela passagem do cortejo imperial e cogita recorrer a D. Pedro Il para dissuadir a mãe da promessa de enviá-lo ao seminário. ${ }^{2}$ O penúltimo (Esaú e Jacó) tem por pano de fundo justamente a transição dos regimes. ${ }^{3} \mathrm{O}$ último (Memorial de Aires) encerra os acontecimentos narrados justamente no ano da Proclamação da República, mas três meses antes da mudança de regime. A corte é o cenário da grande maioria dos seus contos e da totalidade dos seus romances. Todos as peripécias dos seus dez romances se passam na cidade do Rio de Janeiro, com exceção das iniciais (ocorridas entre os capítulos 4 e o 21) e as finais (capítulos 195-201) de Quincas Borba, ${ }^{4}$ e um pequeno segmento de Esaú e Jacó. ${ }^{5}$ Aspectos físicos são frequentemente citados em todo o corpus (os morros, as praias, a baía), culturais (os teatros, cafés, igrejas), sociais (as festas, os saraus, as classes e relações sociais, inclusive a violência da escravidão) e especificamente urbanos: ruas e bairros, tanto ricos como pobres. A Rua do Ouvidor se destaca sobre todas as demais. Ela exibe e simboliza o cerne do caráter especificamente urbano da vida social e política da elite do Rio de Janeiro (MACEDO, 1878). Machado ilustra a natureza essencial da rua para a vida da cidade no conto Tempo de Crise no qual um provinciano chega à corte em meio a uma das diversas crises políticas do parlamentarismo do Segundo Reinado, vivendo um dia de completo turbilhão na Rua do Ouvidor em meio aos boatos sobre os nomes cotados para o novo ministério durante o dia e, à noite, a fashion. ${ }^{6}$

A Rua do Ouvidor resume o Rio de Janeiro. A certas horas do dia, pode a fúria celeste destruir a cidade; se conservar a Rua do Ouvidor, conserva Noé, a família e o mais. Uma cidade é um corpo de pedra com um rosto. O rosto da cidade fluminense é esta rua, rosto eloquente que exprime todos os sentimentos e todas as ideias. (OC, II, 785).

No romance e no conto, a Rua do Ouvidor é o centro do palco da atuação pública das personagens. Propus no meu livro O Ceticismo na obra de Machado de Assis que essa filosofia se estrutura na ficção machadiana quando há uma crise da visão romântica do jovem Machado que opunha uma autenticidade e moralidade da vida rural à vaidade e superficialidade da vida urbana. ${ }^{7}$ Como o universo rural é ausente da ficção machadiana, à "demonização" da vida urbana pública da elite como lugar de exibição de falsas aparências, o jovem Machado opõe o espaço privado, âmbito no qual relações de amizade e amor autênticas e transparentes podiam ser efetivadas. Este quadro é característico de toda produção ficcional machadiana da primeira fase (até antes das Memórias Póstumas de Brás Cubas), configurando, no âmbito ficcional, um cenário epistemológico dogmático (no sentido que os céticos conferem ao termo). ${ }^{8} \mathrm{O}$ personagem ético, "homem de espírito", recusa a vida social pública ("vida exterior") como composta

\footnotetext{
${ }^{2}$ Capítulo 29, intitulado "O Imperador" (OC, I, 835-836).

${ }^{3}$ Aires, o autor ficcional de Esaú e Jacó, soube na "Rua do Ouvidor ... que os militares tinham feito uma revolução, ouviu descrições da marcha, e das pessoas, e notícias desencontradas" (OC, I, 1023). O capítulo é o 60, cujo título é "Manhã de 15 [de Novembro de 1889]".

${ }^{4}$ Esses acontecimentos iniciais que narram o ganho da herança por Rubião em Barbacena (MG) e os finais, quando retorna a sua cidade natal para morrer pobre e miserável, destacam o grande miolo do enredo que se passa no Rio de Janeiro onde sua fortuna é consumida na fogueira das vaidades. O romance expõe a corte urbana como lugar da vaidade e manipulação, onde o ingênuo mineiro perde toda a sua fortuna para o maquiavélico capitalista da capital Palha.

${ }^{5}$ Os acontecimentos narrados do capítulo 91 ao 93 se passam em sua maior parte em Nova Friburgo (OC, I, 1059-1062).

6 "A Rua do Ouvidor é lindíssima à noite. Estão os rapazes às portas das lojas, vendo passar as moças, e como tudo está iluminado, não imaginas o efeito que faz. ... Havia então menos quem cuidasse da política; a noite da Rua do Ouvidor pertence exclusivamente à fashion, que é menos dada aos negócios do Estado" (OC, II, 792).

7 Tradução de Machado de Assis, the Brazilian Pyrrhonian (1994).

${ }^{8}$ Dogmatismo é a crença no sentido de assentimento a uma realidade não evidente. (Cf. SEXTO EMPÍRICO, 1987, I. 13).
} 
por falsas aparências em contraposição a uma verdade transparente no espaço privado. Essa recusa se dá desde os primeiros contos do início dos anos 1860 e, num segundo momento (anos 70, quando são publicados os primeiros romances), já em um quadro mais problematizado, através da decepção amorosa do herói com mulheres voltadas para a "vida exterior". No primeiro momento (anos 60 ) que antecede a produção dos primeiros romances, alguns personagens decepcionados encontram a eticidade e a verdade através do casamento com "muIheres de espírito" eticamente transparentes que também rejeitam a "vida exterior". Num segundo momento da primeira fase dogmática pré-brascubiana de Machado, durante os anos 70 quando aparecem os primeiros romances, estas mulheres éticas, já minoritárias nos contos dos anos 60, desaparecem ou ficam em segundo plano nas tramas, mas sem que o sumiço da verdade que elas representavam viabilize a elaboração de uma perspectiva cética, o que só ocorre na segunda fase, a partir da publicação das Memórias Póstumas de Brás Cubas em 1880, quando o personagem decepcionado, o "homem de espírito", encontra um "lugar" fora do mundo social das falsas aparências que condena, a saber, o lugar de narrador/observador. Cito a seguir dois exemplos, extraídos dos primeiros romances, da visão negativa da "vida exterior" dramatizada na Rua do Ouvidor.

Estácio, protagonista do romance Helena, escreve a esta última de uma fazenda no interior do estado. "Não te direi que gosto da vida agrícola; não gosto, não me dou com ela. Mas viver num recanto como este, a dois passos do mato, a tantas léguas da Rua do Ouvidor, isso creio que se dá com a minha índole. [...] Eu não sei o que é amar o tumulto exterior; acho que é dispersar a alma e crestar a flor dos sentimentos" (OC, I, 330). "Homem de espírito" típico, Estácio vive um romance impossível com Helena, uma "mulher de espírito", como ele avessa à "vida exterior". O romance é impossível por crer ser ela sua meia-irmã e, após revelada a verdade, pelo falecimento da mesma causado pela vergonha da farsa a que foi obrigada a representar por suas condições sociais e econômicas desfavoráveis. Já Jorge, personagem do romance laiá Garcia, romance seguinte a Helena, é o contrário de Estácio. “Elegante, ocupava Jorge um dos primeiros lugares entre os dandies da Rua do Ouvidor; ali podia ter nascido, ali poderia talvez morrer" (OC, I, 400). A mudança do seu amor de Estela para laiá Garcia sinaliza, no romance, justamente a substituição da mulher ética, voltada para a vida íntima, pela voltada para a "vida exterior".

Neste artigo, ilustro esta minha interpretação trazendo o fundo do romance (a cidade, a Rua do Ouvidor) para o primeiro plano, de maneira a mostrar, em primeiro lugar, a importância da vida urbana carioca da elite na estruturação da visão de mundo machadiana e, em segundo, como o romancista vai modificando o seu olhar sobre esta vida urbana (e, portanto, sua visão de mundo) ao longo de sua obra. Para isto comento quatro encontros de narradores que ocorrem na Rua do Ouvidor. Um primeiro ilustra o primeiro momento da primeira fase dogmática (contos publicados na década de 60), quando ainda existem "mulheres de espírito". Os três seguintes ocorrem, respectivamente, nas Memórias Póstumas (1880), em Dom Casmurro (1899) e no Memorial de Aires (1908, último ano de vida do nosso grande escritor). A sequência desses três indica que embora haja em todos esses romances da segunda fase uma perspectiva cética (ausente de toda obra anterior às Memórias Póstumas), a mesma vai se sofisticando numa sequência lógica rumo a um ceticismo original machadiano.

\footnotetext{
${ }^{9}$ Estela é a personagem feminina machadiana que mais exibe a moral estoica ou mesmo, como diz o narrador, cínica. Entre suas características destacam-se "a imperturbável seriedade", o "ar de resolução" e a "natural simplicidade" (OC, l, 407). "Era orgulhosa, ... mas o orgulho ... era uma força, não um vício" (OC, I, 409). "Ao primeiro aspecto dissera-se um Diógenes feminino, cuja capa, através das roturas, deixava entrever a vaidade da beleza que quer afirmar-se tal qual é, sem nenhum outro artifício" (OC, I, 407). laiá, ao contrário, "achou no casamento [com Jorge] a felicidade sem contraste. [...] Se antes de casar, laiá possuía o abecedário da elegância, depressa aprendeu a prosódia e a sintaxe" (OC, I, 506).
} 


\section{Primeiro Encontro: o narrador encontra a Rua do Ouvidor}

Em 1866, com 27 anos de idade, Machado publica no Jornal das Famílias, sob as iniciais do narrador protagonista FS, o conto Felicidade pelo Casamento. Provavelmente por não ser possível estabelecer de forma indubitável a autoria machadiana, o conto não foi incluído nas Obras Completas de 1959, nem na edição mais recente bastante ampliada em quatro volumes publicada em 2015, pela mesma editora. Foi incluído no volume Contos Esparsos editado pelo biógrafo de Machado Magalhães Júnior. A consistência da visão de mundo exibida no conto com a de outros do mesmo período e, principalmente, a adequação de sua estrutura formal ao desenvolvimento da estrutura que caracterizará os grandes romances da segunda fase atestam a autenticidade machadiana do conto.

O conto é narrado em primeira pessoa, forma rara na produção ficcional da primeira fase. Na segunda fase, será frequente nos contos e quase exclusiva nos romances. ${ }^{10} \mathrm{FS}$, o narrador-protagonista, apresenta inicialmente um discurso pessimista que lembra o de Brás Cubas, ressaltando as misérias da vida e citando Pascal e o livro do Eclesiastes. ${ }^{11}$ Sua misantropia é, como a dos demais "homens de espírito" dos outros contos desta fase, motivada por uma decepção amorosa: sua amada preferiu um homem vulgar. É neste estado pessimista de espírito que desembarca no Rio de Janeiro, proveniente do interior, para resolver negócios da família. Pouco depois, curioso para conhecer a corte, FS visita a cidade e ao relatar as suas impressões se detém na descrição do que observou na Rua do Ouvidor.

Passei os primeiros dias a ver a cidade. Vi muita gente boquiaberta diante das vidraças da Rua do Ouvidor, manifestando no olhar o mesmo entusiasmo que eu quando contemplava os meus rios e as minhas palmeiras. Lembrei-me com saudade das minhas antigas diversões, mas tive o espírito de não condenar aquela gente. Nem todos podem compreender os encantos da natureza, e a maioria dos espíritos só se nutrem de quinquilharias francesas. Agradeci a Deus não me ter feito assim. Não me detenho nas impressões que me causou a capital. Satisfiz a curiosidade e voltei aos meus hábitos e isolamento. ${ }^{12}$

É na Rua do Ouvidor que FS verifica a vaidade da corte. Esta é das lojas que vendem as "quinquilharias francesas" e das pessoas que as admiram e consomem. A constatação corrobora sua visão de mundo, contribuindo para a narrativa pessimista que escreve. Reforça sua rejeição da vida social: "vida exterior" de aparências e superfluidades onde não têm lugar valores morais como integridade, sinceridade e desprendimento. Ocorre que FS adoece e é tratado por um médico, o Dr. Magalhães, que se lhe revela, pelos interesses, conversa, atitude de despojamento e abertura em relação ao paciente, um autêntico "homem de espírito". A visão pessimista do mundo nesta fase é claramente cristã: as referências a Pascal e à Bíblia não são casuais. ${ }^{13}$ Mas este pessimismo tem por contraponto, neste primeiro momento da primeira fase (anos 60), o otimismo cristão da redenção. Nestes contos dos anos 60, embora minoritárias, há "mulheres de espírito" que comungam a eticidade dos "homens de espirito" com quem estabelecem a "paz doméstica"

\footnotetext{
${ }^{10} \mathrm{O}$ único romance da segunda fase que não é narrado em primeira pessoa é Quincas Borba. Esaú e Jacó, embora formalmente narrado em terceira pessoa, é ficcionalmente atribuído a Aires que figura como personagem do romance. É, portanto, a sua perspectiva que determina o foco narrativo.

11 O pessimismo do Eclesisastes aparece em diversas afirmações como as seguintes: "[A]umentar a ciência é aumentar a dor" (Ecl. 1,18). “Detestei a vida porque me aborrece tudo quanto se faz sob o sol, pois tudo é vaidade e busca de vento” (Ecl. 2,17). "Melhor [...] o dia da morte que o dia do nascimento" (Ecl. 7,1). O Eclesiastes era o livro bíblico preferido de Machado. Em seu último romance, o Memorial de Aires, escreve o narrador: "Tudo é fugaz neste mundo. Se eu não tivesse os olhos adoentados dava-me a compor outro Eclesiastes, à moderna, posto nada deva haver moderno depois daquele livro. Já dizia ele que nada era novo debaixo do sol, e se não era então, não o foi nem será nunca mais. Tudo é assim contraditório e vago também" (OC, I, 1139).

12 "Felicidade pelo Casamento" (MACHADO DE ASSIS, 1966, p. 231).

${ }^{13}$ Para a influência do pessimismo cristão na vertente cética da filosofia colonial, ver Margutti (2013).
} 
através do matrimônio. Estas mulheres representam a verdade possível de ser encontrada pelo homem de espírito que assim se livra das falsas aparências contraditórias que o perturbavam. Estas aparências eram geradas pelas mulheres voltadas para a "vida exterior" por quem se apaixonavam, pois elas ora aparentavam corresponder, ora não corresponder, ao amor do protagonista. ${ }^{14}$ A infelicidade de FS dura somente enquanto não encontra a "paz doméstica" do Dr. Magalhães. O médico tinha a fisionomia de Abraão, o personagem do Velho Testamento que é o cavaleiro da fé. ${ }^{15}$ Sua intimidade doméstica estabelecida em Andaraí, na época um dos bairros menos urbanos da cidade, incluía também um irmão e a filha Ângela. Como se detentora de uma natureza angelical, Ângela é inteiramente voltada para a "paz doméstica", compondo um ambiente que "excluía todas as superfluidades sem valor para dar lugar a tudo o que entra nas preferências dos espíritos cultivados". ${ }^{16} \mathrm{O}$ destino tendo lançado o narrador em uma ilha em meio a vida mundana corrompida da corte, F.S descobre que nem tudo é miséria e vaidade. Perde a misantropia que o levou a escrever narrativas pessimistas, casa-se com Ângela, com quem, juntamente com o sogro e o irmão do sogro, abandona a corte, retornando para o interior. A Felicidade pelo Casamento é coroada no final com o anúncio de um filho (nascido na província e não na corte). A trajetória do personagem narrador é exatamente inversa da dos narradores dos grandes romances da segunda fase. Brás Cubas, Dom Casmurro e Aires não encontraram "felicidade pelo casamento" (apesar da tentativa dos dois primeiros), não tiveram filhos (no caso de Dom Casmurro, esta foi a desconfiança que lhe trouxe maior infelicidade) e não deixaram a cidade do Rio de Janeiro. Por outro lado, a vida narrativa e investigativa da condição humana de FS desaparece quando encontra a verdade, contrariamente a Brás Cubas, Bento Santiago e o Conselheiro Aires que, continuando a zetesis, ${ }^{17}$ caracterizam-se como narradores. ${ }^{18}$

Esta visão negativa da vida urbana permanece, se sofisticando, pelo menos até antes de Memorial de Aires. Neste primeiro momento da produção ficcional machadiana (primeiros contos escritos nos anos 1860), o casamento se contrapõe à vida social cujo palco central é a Rua do Ouvidor, lugar de exibição de aparências falsas em contraposição à transparência das relações privadas.

\section{Segundo Encontro: o narrador encontra e analisa a vaidade humana na Rua do Ouvidor ${ }^{19}$}

O segundo encontro aqui examinado ocorre em 1880, quatorze anos após o primeiro, ocasião da publicação das Memórias Póstumas de Brás Cubas. No meu livro supracitado localizo nesse romance o surgimento de uma perspectiva cética na ficção machadiana, com o posicionamento do "homem de espírito" desiludido no foco narrativo do romance. Brás Cubas é prete-

\footnotetext{
${ }^{14}$ Segundo Sexto Empírico, o futuro cético começa a filosofar "with the object of passing judgment on the sense-impressions and ascertaining which of them are true and which false, so as to attain quietude thereby" (PH I. 26). O dogmático imagina poder encontrar esta paz fazendo o discernimento, isto é, eliminando as aparências falsas e encontrando a verdade. O cético se depara com aparências contrárias de igual peso e suspende o juízo.

${ }^{15}$ Sobre Abraão como cavaleiro da fé, ver Kierkegaard (1979).

${ }^{16}$ Contos esparsos, p. 233.

17 "The Skeptic school [...] is also called 'Zetetic' from its activity in investigation and inquiry" (PH I.7). A skepsis é permanente à medida que o cético não encontra a verdade que procura.

${ }^{18}$ Brás Cubas esclarece logo no início das suas memórias que não é "propriamente um autor defunto, mas um defunto autor, para quem a campa foi outro berço" $(\mathrm{OC}, 1,511)$. Embora menos distanciados do mundo da vida, também Bento e Aires já estão retirados à condição de, respectivamente, recordador e observador deste mundo. Em todos os casos há um divórcio entre a perspectiva filosófica e a inserção plena no mundo da vida.

${ }^{19}$ Cabe o termo "vaidade" aqui em todos os sentidos dados no Novo Dicionário da Língua Portuguesa de Aurélio Buarque de Holanda Ferreira (Rio de Janeiro: Nova Fronteira, 1975): "1. Qualidade do que é vão, ilusório, instável ou pouco duradouro. 2. Desejo imoderado de atrair admiração ou homenagens. 3. V. vanglória. 4. Presunção, fatuidade. 5. Coisa fútil ou insignificante; frivolidade, futilidade, tolice".
} 
rido por Virgília que prefere desposar outro jovem mais ambicioso e promissor politica e socialmente, o Lobo Neves. ${ }^{20}$ Sua escolha mostra-se acertada pois ele, com efeito, logo se elege Deputado, sendo posteriormente indicado para presidir uma província. Brás Cubas se torna amigo do casal e amante de Virgília.

No final do prolongado relacionamento amoroso com a esposa do amigo, de quem gozava intimidade e confiança, o caso se torna quase público. Este é o contexto de um encontro casual de Brás Cubas com Lobo Neves na Rua do Ouvidor, relatado postumamente pelo narrador com sua "pena da galhofa e tinta da melancolia" (OC, I, 511). Desta perspectiva, o narrador analisa o controle "virtuoso" que a "vida exterior" exerce sobre as paixões viciosas dos indivíduos.

Poucas horas depois encontrei Lobo Neves, na Rua do Ouvidor, falamos da presidência [da província para a qual Lobo Noves havia sido designado] e da política. Ele aproveitou o primeiro conhecido que nos passou à ilharga, e deixou-me, depois de muitos cumprimentos. Lembrava-me que estava retraído, mas de um retraimento que forcejava por dissimular. Pareceu-me então [...] que ele tinha medo - não medo de mim, nem de si, nem do código, nem da consciência; tinha medo da opinião. Supus que esse tribunal anônimo e invisível, em que cada membro acusa e julga, era o limite imposto à vontade do Lobo Neves. Talvez já não amasse a mulher [...]. Cuido [...] que ele estaria pronto a separar-se [...]; mas a opinião, essa opinião que lhe arrastaria a vida por todas as ruas, que abriria minucioso inquérito acerca do caso, que coligiria uma a uma todas as circunstâncias, antecedências, induções, provas, que as relataria na palestra das chácaras desocupadas, essa terrível opinião, tão curiosa das alcovas, obstou à dispersão da família. Ao mesmo tempo tornou impossível o desforço, que seria a divulgação. Ele não podia mostrar-se ressentido comigo, sem igualmente buscar a separação conjugal; teve então de simular a mesma ignorância de outrora, e, por dedução, iguais sentimentos. (OC, l, 610).

\section{O episódio é o objeto do capítulo/comentário seguinte: "A solda"}

A conclusão, se há alguma no capítulo anterior, é que a opinião é uma boa solda das instituições domésticas. [...] é uma boa solda a opinião, e tanto na ordem doméstica, como na política. Alguns metafísicos biliosos têm chegado ao extremo de a darem como simples produto da gente chocha ou medíocre, ${ }^{21}$ mas é evidente que [...] bastava considerar os efeitos salutares da opinião, para concluir que ela é obra superfina da flor dos homens, a saber, do maior número. (OC, 1, 610-611).

Embora com ódio mortal de Brás, Lobo Neves é constrangido pelo medo da opinião a simular (veja a falsa aparência exibida na Rua do Ouvidor flagrada pelo defunto-autor) a antiga amizade, pois do contrário tornaria público o seu conhecimento da traição. Note que ele já sabia - ou ao menos desconfiava - que a relação adúltera da mulher já era pública, mas importava não tornar público o seu conhecimento pelas consequências indesejáveis sociais e políticas que resultariam das atitudes que teria de tomar. $O$ interesse político e a vaidade impedem o extravasamento do sentimento de ódio em relação a Brás Cubas. O mesmo vale para a manutenção do casamento com Virgília, pois a separação no contexto moralista da época revelaria que ele sabia da traição. Brás Cubas conclui que a opinião é uma solda das instituições domésticas e públicas. Ela não é mais simplesmente falsa. Com toda sua falsidade é o cimento da "vida exterior" do homem corrompido que bloqueia a expressão de sentimentos instintivos antissociais. É o fundamento da "civilização" na chave antropológica cristã agostiniana que Machado recepcionou principalmente através da sua intensa leitura de moralistas franceses como La Rochefoucauld e Pascal, cujos Pensamentos é a principal fonte filosófica das Memórias

\footnotetext{
20 "Marquesa, porque eu serei marquês" é o título do capítulo (93) no qual Brás Cubas relata sua perda de Virgília para Lobo Neves.

${ }^{21}$ Um exemplo de tal metafísico bilioso é FS, narrador de Felicidade pelo Casamento.
} 
Póstumas. ${ }^{22}$ Neste romance, Machado adapta ao cenário da elite carioca a análise pascaliana da "miséria do homem sem Deus", mas, contrariamente a FS, rejeita a crença pascaliana na "felicidade do homem com Deus".23 "Deixa lá dizer Pascal que o homem é um caniço pensante. Não; é uma errata pensante, isto sim. Cada estação da vida é uma edição, que corrige a anterior, e que será corrigida também, até a edição definitiva, que o editor dá de graça aos vermes" (OC, I, 547). A análise brascubiana da opinião como solda das instituições corresponde exatamente ao que pensa Pascal no âmbito da "miséria do homem sem Deus", por exemplo no fragmento La 93 dos Pensamentos.

Reversão contínua do pró ao contra. Mostramos portanto que [1] o homem é vão pela estima que tem por coisas que não são essenciais. E todas estas opiniões são destruídas. Mostramos em seguida que [2] todas estas opiniões são muito sãs, de modo que estando todas essas vaidades bem fundadas, o povo não é tão vão como se diz. E deste modo destruímos a opinião que destruía a do povo. Mas também é necessário destruir esta última proposição [opinião 2] e mostrar que [3] continua verdadeiro que o povo é vão [opinião 1], embora suas opiniões sejam sãs, pois ele não sente a verdade onde ela está e colocando-a onde não está suas opiniões são muito falsas e malsãs.

A opinião [1] corresponde à posição de FS que denuncia a vaidade das opiniões comuns, a admiração vã pelas "quinquilharias francesas" expostas na Rua do Ouvidor. Brás Cubas corrige FS (que é representativo da perspectiva filosófica dogmática da primeira fase de Machado) assumindo a opinião [2], por exemplo na sua reflexão sobre o encontro com Lobo Neves nesta mesma Rua do Ouvidor e, implicitamente, também [3]: a vida humana não deixa de ser miserável e vã pela funcionalidade social da opinião pública. A perspectiva cética que apresenta é a de um pessimismo de matiz agostiniana-pascaliana sem a alternativa otimista cristã.

Na perspectiva antropológica agostiniana-pascaliana, as instituições sociais e as opiniões públicas que as sustentam são simulacros que viabilizam o homem corrompido, escravo das concupiscências. As instituições sociais servem justamente para evitar a destruição recíproca de indivíduos marcados por paixões libidinosas. Assim, diferentemente do primeiro encontro, a vida social - que guarda a negatividade e falsidade moral - está internalizada e sofisticada, já não se apresentando no romance a alternativa de sua simples rejeição. A vaidade própria da Rua do Ouvidor já não é algo exterior como aparece ao olhar de FS, mas, na visão de Brás Cubas, algo que penetra até o fundo do coração dos homens, inclusive dele mesmo enquanto vivo. Todos a carregam onde quer que estejam, seja na Rua do Ouvidor, no Andaraí ou no isolamento rural. ${ }^{24}$ Nos termos da analogia com o pirronismo aqui proposta, podemos falar de uma perspectiva cética no sentido que a falsa aparência penetra e corrompe o que era a realidade na fase dogmática. O casamento de Virgília com Lobo Neves, assim como a amizade deste com Brás Cubas, apresentam toda a negatividade moral reservada na fase anterior à "vida exterior". É como se a Rua de Ouvidor invadisse a intimidade doméstica liquidando com a sua "paz". O observador/investigador precisará assim continuar a sua zetesis em busca da ataraxia.

\footnotetext{
22 Sobre a influência de Pascal no pensamento brasileiro na época de Machado em geral e em sua obra em particular, ver a tese defendida por Alex Lara Martins, O anjo e a besta: Pascal, Machado de Assis e a descristianização do ceticismo, (2018).

${ }^{23}$ PASCAL, 1963, frag. La 6. [Tradução Nossa].

${ }^{24}$ Um conto publicado no ano seguinte ao das Memórias Póstumas ilustra magistralmente esta nova antropologia. Trata-se de $O$ Espelho: esboço de uma nova teoria da alma humana. O personagem Jacobina, desesperado por encontrar-se absolutamente só na fazenda de uma tia, não mais enxerga a sua imagem num espelho até vestir o seu uniforme de alferes, através da qual reencontra sua identidade social, sua "alma exterior" (OC, II, 351-352)
} 


\section{Terceiro Encontro: o narrador encontra a própria vaidade na Rua do Ouvidor}

No romance seguinte às Memórias Póstumas, Quincas Borba, Machado abandona o foco restritivo que viabiliza a perspectiva cética no romance. Retoma este foco dezenove anos depois das Memórias Póstumas com Dom Casmurro. A perspectiva cética é assim novamente viabilizada do ponto de vista formal e tem conteúdo em linha de continuidade com a anterior, mas intensificando o ceticismo.

Em suas memórias Bento Santiago relata dois períodos sequenciais bem distintos de sua vida. O primeiro vai do capítulo 12 ("Na Varanda"), quando se descobre apaixonado por Capitu, sua vizinha, ${ }^{25}$ até o capítulo 101 ("No céu"), quando consuma o casamento na lua de mel no alto da Tijuca. ${ }^{26}$ É o período heroico da conquista da vitória sobre a promessa da mãe em fazer-lhe padre e das emoções prazerosas do amor idílico adolescente. Esta etapa culmina com a conquista do "céu", expressão cristã para a bem-aventurança vivida no alto da Tijuca, longe da Rua do Ouvidor. Bentinho vive este momento com Capitu assim como FS viveu com Ângela, cujo nome denota espécie celestial, em Andaraí, bairro do Rio que na época de Felicidade pelo Casamento ficava tão socialmente distante da "vida exterior" como o alto da Tijuca. O segundo período da vida de Bento narrado pelo autor Casmurro vai do capítulo 102 ("De casada"), quando Capitu fica entediada com o "céu" e quer voltar "à terra", ${ }^{27}$ até o capítulo 140, não por acaso intitulado "Volta da Igreja", que marca o rompimento do casal. Contrariamente a FS, Bentinho encontra a infelicidade pelo casamento. É a fase infernal de sua vida, consumida por cismas (cap. 126: "Cismando"), "dúvidas sobre dúvidas" (título do capitulo 115), "embargos de terceiros" (cap. 113) e "catástrofe" (cap. 121).

Após passar então uma semana "no céu" em lua-de-mel com Capitu, Bentinho desce incialmente contrariado do alto da Tijuca. Já retirado, o narrador casmurro recorda como "De casada", título do capítulo que descreve a atuação pública do casal de volta à vida social, significou a perda de sua perspectiva ingênua do casamento. Bento se descobre na Rua do Ouvidor como tendo adquirido, justamente pelo casamento, uma dimensão "exterior" (como Jacobina descobre a "alma exterior" no conto O Espelho).

A alegria com que pos o seu chapéu de casada, e o ar de casada com que me deu a mão para entrar e sair do carro, e o braço para andar na rua, tudo me mostrou que a causa da impaciência de Capitu eram os sinais exteriores do novo estado. Não lhe bastava ser casada entre quatro paredes e algumas árvores; precisava do resto do mundo também. E quando eu me vi embaixo, pisando as ruas com ela, parando, olhando, falando, senti a mesma coisa. Inventava passeios para que me vissem, me confirmassem e me invejassem. Na rua, muitos voltavam a cabeça curiosos, outros paravam, alguns perguntavam: "Quem são?" e um sabido explicava: “Este é o Doutor Santiago, que casou há dias com aquela moça, D. Capitolina, depois de uma longa paixão de crianças; moram na Glória, as famílias residem em Mata-cavalos". E ambos os dois: "É uma mocetona!" (OC, 1, 907).

Desde a produção ficcional dos anos 70 que inclui, além de muitos contos, os primeiros romances, não há mais "mulheres de espírito" protagonizando as narrativas. Todas as protagonistas são voltadas para a "vida exterior". A aparência é agora fundamental para a mulher, e o narrador descobre, agora também para Bentinho, que perde a perspectiva ingênua romântica da paz doméstica afastada da vida social e adota uma perspectiva casmurra (como FS antes de

\footnotetext{
25 "Com que então eu amava Capitu, e Capitu a mim?" (OC, I, 819).

26 "S. Pedro, que tem as chaves do céu, abriu-nos as portas dele, fez-nos entrar [...]. Descansa que não farei descrição alguma, nem a língua humana possui formas idôneas para tanto" $(\mathrm{OC}, 1,906)$.

27 “Não obstante, achei que Capitu estava um tanto impaciente por descer” (OC, I, 907).
} 
conhecer e se casar com Ângela). Há uma inversão em relação a este conto da juventude. No Primeiro Encontro, o casamento era o lugar alternativo ao espaço público-social representado pela Rua do Ouvidor. Este Terceiro Encontro mostra que o casamento não se consuma fora deste mesmo espaço. A dimensão social, "de vida exterior", passa a ser parte essencial do que antes era a alternativa de verdade a esta mesma "vida exterior". A descida da Tijuca para a Rua do Ouvidor significa que o casamento adentra o espaço público (como o Segundo Encontro mostra a intrusão do espaço público no casamento). A narração deste Terceiro Encontro não traz propriamente uma análise do papel da opinião pública (da Rua do Ouvidor) na vida humana, como no Segundo. Não se trata mais de revelar uma realidade irracional/passional constrangida pelas aparências sociais. Neste Terceiro Encontro a entrada do casamento na Rua do Ouvidor significa o ocultamento da verdade pela aparência. A vida de casado narrada pelo autor Casmurro revela, do ponto de vista subjetivo, o contrário da paz doméstica dos contos de 1860, mas também não flagra traições no âmbito privado e hipocrisia e dissimulação no público, como nas Memórias Póstumas. Desaparece a capacidade do narrador de apontar a dualidade entre aparência (social) e realidade (doméstica), embora a realidade continue presente como um fantasma, atormentando Bento Santigado por sua natureza incognoscível (de fato foi ou não traído?). O ponto de vista narrativo do ex-marido (de Bento) substitui o ponto de vista narrativo do ex-amante (de Brás Cubas). Enquanto este último é apto a flagrar e denunciar a imoralidade, a hipocrisia e a vaidade, o primeira é marcado pela incerteza e pela obscuridade. A inversão é total em relação ao contexto dos contos de 1860, pois Capitu aparecia transparente para Bento antes do casamento no primeiro período rememorado na narrativa, embora a mudança para a perspectiva casmurra se volte também para este período de sua vida, colocando em dúvida a sua perspectiva até então feliz. ${ }^{28}$

\section{Quarto Encontro: o narrador encontra o seu lugar como observador na Rua do Ouvidor}

Machado publicou o seu último romance, o Memorial de Aires, nove anos após Dom Casmurro. A crítica considera que neste romance Machado mitiga o seu pessimismo, conciliando-se com a vida. ${ }^{29} \mathrm{~A}$ pena do narrador (Conselheiro Aires) já não é galhofeira como a de Brás Cubas, e embora a tinta destilada ainda seja de melancolia, o tom é mais suave, resignado e conformista. O romance não traz um narrador como Brás que rememora suas paixões, sua hipocrisia, sua vaidade e as muitas misérias que encontrou pela vida. Também não traz um narrador como Bento que rememora seus amores idílicos, os quais depois julga terem sido ilusões infantis, e que terminam em dúvidas e catástrofes. Nem ex-amante, nem ex-marido, no Memorial o olhar do narrador volta-se para si somente enquanto observador e contemplador dos outros, em particular da bela viúva Fidélia, de quem se torna amigo através da frequentação da "paz doméstica" do casal Aguiar, "pais postiços" da jovem viúva.

Como Dom Casmurro, Memorial de Aires também é dividido em duas partes bem demarcadas. Ficcionalmente o romance é uma parte de um diário deixado inédito pelo falecido

\footnotetext{
28 "O resto é saber se a Capitu da Praia da Gloria [da vida de casados] já estava dentro da de Mata-Cavalos [dos amores adolescentes de vizinhos] ... se te lembras bem da Capitu menina, hás de reconhecer que uma estava dentro da outra, como a fruta dentro da casca" (OC, I, 942). A Rua de Mata-Cavalos é atualmente a Rua do Riachuelo no bairro da Lapa, próximo ao centro do Rio de Janeiro. As duas fases da vida de Bento têm por cenários urbanos um bairro mais central, do qual é nostálgico, e um litorâneo na direção sul, onde viveu mais intensamente suas dúvidas angustiantes. O amigo Escobar, que Bento crê ser o pai do filho de Capitu, ao casar-se com a amiga de Capitu Sancha vai morar na praia seguinte na direção sul, a Praia do Flamengo.

${ }^{29} \mathrm{Cf}$. Barreto Filho, "O Romancista”. In: OC, I, 112.
} 
Conselheiro Aires. Capítulos da narrativa são assim substituídos por registros cujos títulos são datas. A primeira parte do romance ocorre em 1888, de 9 de janeiro a 28 de dezembro. Vai da primeira aparição da viúva a Aires, contrita frente ao túmulo do finado marido no cemitério de São João Batista, até a ocorrência de sua nova paixão, não pelo narrador, mas por Tristão, um português afilhado do casal Aguiar residente em Lisboa que vem ao Rio visitar os padrinhos. A segunda parte vai de 2 de janeiro, quando assumem o relacionamento amoroso, ${ }^{30}$ a 30 de agosto de 1889, data do embarque dos recém-casados para Portugal, causando grande tristeza ao casal Aguiar que esperava mantê-los no âmbito de sua "paz doméstica". Com a partida do jovem casal e o afastamento de Aires que perdeu seu objeto de contemplação estética (Fidélia), a "paz doméstica" dos Aguiar vira uma "paz de cemitério". A marcação do tempo é crucial na perspectiva cética do narrador que diz a um tio de Fidélia, após dela despedirem-se no cais do porto:" - Desembargador, se os mortos vão depressa, os velhos ainda vão mais depressa que os mortos. ... Viva a mocidade!" (OC, I, 1198). A primeira parte - exatamente um ano - foi o tempo necessário para a viúva "esquecer" o finado marido, apaixonando-se novamente. A segunda parte - sete meses - foi o tempo que levou para "esquecer" os velhos pais postiços e voltarem para a "Rua do Ouvidor" de Lisboa, onde o noivo já começava o que se anunciava uma notável carreira política. Esta é a melancolia do romance que poderia ser visto, como o narrador deixa implícito, como um novo Eclesiastes.

Nada menos do que cinco cenas do romance têm lugar na Rua do Ouvidor: um recorde em toda produção literária machadiana. É onde Aires fica sabendo do principal acontecimento político do ano, ocorrido e registrado no seu Memorial em 13 de maio de 1888: “Enfim, lei. Nunca fui, nem o cargo [de diplomata] me consentia ser propagandista da abolição, mas confesso que senti grande prazer quando soube da votação final do Senado e da sanção da Regente. Estava na Rua do Ouvidor, onde a agitação era grande e a alegria geral" (OC, I, 1116). ${ }^{31}$ Se este primeiro encontro do narrador na Rua do Ouvidor é com a política, os outros são com os demais personagens. Em 23 de julho de 1888 Aires encontra Aguiar na Rua do Ouvidor onde o amigo Ihe diz que visitará Fidélia na fazenda para dar-lhe os pêsames pela perda do pai $(O C, I, 1126)$. O narrador obtém assim informação sobre Fidélia, o seu "objeto de estudo" (anotação de 12 de abril de 1888, OC, I, 1115). Não são somente informações públicas que se obtém na Rua do Ouvidor. Somente quatro dias depois do encontro com Aguiar, encontra novamente com este e com Tristão, que ainda não conhecia pessoalmente, novamente na Rua do Ouvidor. "Vi hoje o Tristão descendo a Rua do Ouvidor com o Aguiar, adivinhei-o por este e pelo retrato. Trazia no vestuário alguma coisa que, apesar de não diferir da moda, cá e lá, lhe põe certo jeito particular e próprio" (OC, I, 1131). O narrador chama a atenção para o vestuário de Tristão (lembremos que a Rua do Ouvidor é associada na ficção machadiana às vitrines e à fashion). Entretanto, apesar da preocupação com a aparência exterior, o personagem já não é visto pelo narrador como um indivíduo vulgar. No encontro seguinte o narrador se coloca na posição de esteta, na qual acaba por encontrar o seu lugar, em contraposição à perspectiva libidinosa de Tristão. Anota no seu Memorial em 22 de setembro de 1888:

Encantadora Fidélia! Não escrevo isto porque a deseje, mas porque é assim mesmo: encantadora! Pois não é que esta criatura de Deus, encontrando-se comigo de manhã, veio agradecer-me a companhia que fiz aos seus amigos [o casal Aguiar, "pais postiços" de Fidélia] do Flamengo, na noite de 18 ? ... Fidélia sorriu agradecida e despediu-se. Eu - aqui

\footnotetext{
30 "1889. 2 de janeiro. Enfim, amam-se!" (OC, I, 1174).

${ }^{31}$ Cabe ressaltar que este mesmo Aires em Esaú e Jacó fica sabendo da Proclamação da República também na Rua do Ouvidor, como indicado acima. É notável o contraste entre o entusiasmo com que recebe a notícia da abolição da escravatura (entusiasmo raro dada sua personalidade) e a frieza com que recebe a notícia da instauração da República.
} 
o digo ante Deus e o Diabo, se também este senhor me vê a encher o meu caderno de lembranças - eu deixei-me ir atrás dela. Não era curiosidade, menos ainda outra coisa, era puro gosto estético. Tinha graça andando ... No Largo do S. Francisco estava um carro dela, perto da igreja. Íamos da Rua do Ouvidor, a dez passos de distância ou pouco mais. Parei na esquina, via-a caminhar, parar, falar ao cocheiro, entrar no carro, que partiu logo pela travessa, naturalmente para os lados de Botafogo. Quando ia voltar dei com o moço Tristão, que ainda olhava para o carro, no meio do largo, como a tivesse visto entrar. Ele vinha agora para a Rua do Ouvidor, e também me viu; detive-me à espera. Tristão trazia os olhos deslumbrados, e esta palavra na boca: - Grande talento! (OC, I, 1152).

O quinto e último encontro na Rua do Ouvidor que acontece no romance é o que destaco nesta seção, nele assinalando o quarto momento que marca a alteração derradeira na perspectiva cética machadiana. Depois do encontro em que conhece Tristão e o anterior no qual ambos admiram - em atitudes distintas - a bela viúva, o desenlace se dá no encontro com ambos já formados como casal. Esta cena do romance é idêntica à do passeio de Bento e Capitu, recém-casados, descrita na seção anterior ("Terceiro Encontro"). Fidélia e Tristão passeiam pela Rua do Ouvidor logo após a lua de mel onde encontram Aires.

Hoje [11 de junho de 1889] apareceram-me os recém-casados pela primeira vez, encontro casual, na Rua do Ouvidor ...; iam a compras. Gostei de os ouvir, e ainda mais de a ver. A graça com que ela dava o braço ao marido e deslizava na rua era mais completa que a anterior ao casamento: obra do casamento e da felicidade. lam ouvindo, iam falando, iam parando aos mostradores. (OC 1 1193).

O narrador já não é um analista dos frutos "virtuosos" de um fundo vicioso (Brás) ou memorialista de uma experiência feliz de casado no espaço público (Bento) - que depois reinterpreta como tendo sido ilusória, embora reconhecendo que também se goza com a ilusão. A veIhice do Conselheiro o fez conformar-se com a condição de observador. Comparação com o primeiro observador da Rua do Ouvidor, o FS (ver "Primeiro Encontro" acima), revela a guinada na visão de mundo ocorrida na ficção. Aires é observador do casamento, outrora alternativa de eticicidade e de verdade à vida exterior das falsas aparências, que agora se integra à Rua do Ouvidor.

A situação de casada de Fidélia a torna, aos olhos do observador, ainda mais bela do que já era enquanto viúva. A apreciação estética da beleza da mulher é ressaltada na referência aos sentidos do esteta, com destaque, naturalmente, para a visão ("gostei de os ouvir, e ainda mais de a ver"). ${ }^{32} \mathrm{O}$ narrador muda de lugar, comparativamente ao Terceiro Encontro. Note a diferença entre a sua perspectiva e a imaginada do público nos encontros anteriores. Agora ele é público: está boquiaberto como os cariocas percebidos por FS (Felicidade pelo Casamento) face às vitrines da Rua do Ouvidor; compõe a opinião (observada e analisada por Brás Cubas em suas Memórias Póstumas); vê um casal recém-casado desfilando pela Rua do Ouvidor, exatamente como Bento Santiago se viu com Capitu, admirando a beleza de Fidélia recém-casada com o marido, exatamente como Bentinho imaginou a admiração pelo público da beleza de Capitu ("Uma mocetana!") recém-casada consigo mesmo.

O personagem-narrador agora é um observador afastado e conciliado com o seu lugar, que enfim encontrou a paz mental na perspectiva cética. Não é um observador surpreendido e decepcionado com a Rua do Ouvidor, como no Primeiro Encontro. Não é um observador que flagra os mecanismos de controle social e de sujeição individual na Rua do Ouvidor, como no Segundo Encontro. Não é um observador de si mesmo, que rememora, distanciado no tempo, a perda da ingenuidade no reconhecimento da força da vida social, como no Terceiro Encontro.

\footnotetext{
32 A fruição da beleza de e emanada por Fidélia é destacada muitas vezes pelo observador/narrador ao longo da narrativa. Por exemplo, ao ouvi-la e vê-la no piano (OC, I, 1140).
} 
Agora ele é simplesmente observador, que reconhece a importância da vida social exposta no cenário urbano, na Rua do Ouvidor. Não é por acaso que verificamos no último romance de Machado a presença tão frequente de sítios da cidade (além das cinco aparições da Rua do Ouvidor, há também encontros no Largo do Machado e de S. Francisco, na prainha e no Catete) e isto num romance que focaliza a vida de personagens avessos à festas e teatros, que vivem uma vida simples e íntima. Na analogia epistemológica, o que temos é o narrador cético abandonando uma busca vã por uma realidade em si, despida de aparências. A dualidade aparência/ realidade estava presente no primeiro encontro e pressuposta nos demais. Somente aqui o olhar não mais busca (indaga sobre) o que estaria por trás da aparência, fixando-se nela mesma, se conciliando e se conformando com ela, valorizando o que já percebia desde as primeiras narrativas, mas que reprovava moralmente: o valor estético da aparência.

A perspectiva cética-estética do Conselheiro Aires é um desdobramento singular machadiano, fruto de seu fazer e do seu pensar sobre a arte, e da construção e reconstrução ficcional das perspectivas céticas anteriores originalmente elaboradas por filósofos da tradição cética como Pascal e Sexto Empírico.

\section{Referências}

BÍBLIA. Mensagem de Deus. São Paulo: Loyola, 1983.

BUARQUE DE HOLANDA. A. de. Novo Dicionário da Língua Portuguesa. Rio de Janeiro: Nova Fronteira, 1975.

KIERKEGAARD, S. Temor e Tremor. Trad. M. Marinho. São Paulo: Abril Cultural, 1979. (Col. Os Pensadores).

MACEDO, J. M. de. Memórias da Rua do Ouvidor. Rio de Janeiro: Typographia Perseverança, 1878. MACHADO DE ASSIS, J. M. Obra completa. 3 vols. Rio de Janeiro: J. Aguilar, 1959.

MACHADO DE ASSIS, J. M. Contos Esparsos. Editados por R. Magalhães Júnior. Rio de Janeiro: Edições de Ouro, 1966.

MAIA NETO, J. R. O Ceticismo na Obra de Machado de Assis. São Paulo: Annablume, 2007. Tradução de Machado de Assis, the Brazilian Pyrrhonian. West Lafayette: Purdue U. Press, 1994. MARGUTTI, P. História da Filosofia do Brasil: O Brasil colonial (1500-1822). São Paulo: Loyola, 2013. MARTINS, A. L. O anjo e a besta: Pascal, Machado de Assis e a descristianização do ceticismo. Belo Horizonte. 322f. Tese (Doutorado em Filosofia). UFMG, 2018.

PASCAL, B. Pensées. Em: Oeuvres completes. Paris: Du Seuil, 1963.

SEXTO EMPÍRICO. Outlines of Pyrrhonism. Translated by R. G. Bury for the Loeb Classical Library. Cambridge: Harvard University Press, 1987. 


\section{ANEXO \\ A Rua do Ouvidor na primeira recepção da primeira obra escrita ficcionalmente pelo Conselheiro Aires}

Resenha de Esaú e Jacó, publicada por Hélio de Seixas Fernandes, Os Leitores de Machado de Assis (São Paulo: EDUSP, 2004, p. 440-441) escrita por B (segundo Hélio Fernandes, "abreviação de Olavo", p. 441n), originalmente publicada em A Notícia, Rio de Janeiro, 26 e 27 de novembro de 1904, p. 2. Transcrevo-a na íntegra.

“[...] graças ao talento do escritor, a vida carioca, sendo uma vida cosmopolita e sem originalidade, serve de base para a creação de um litteratura orginalissima [...].

"Em todo o Brasil, no Norte como no Sul, o Rio de Janeiro não é muito amado: na opinião de todos os provincianos, o Rio de Janeiro não é o Brasil: é um ponto de reunião comercial, uma vasta Bolsa em que todas as raças e todas as nacionalidades se confundem, uma cidade sem caracter próprio, uma cosmópolis imprecisa e vaga... Não contesto isso; apenas contesto que um escriptor carioca, descrevendo a vida do Rio de Janeiro, seja fatalmente forçado a escrever livros sem originalidade. A vida do Rio é, na essência, egual à vida de todas as outras cidades, um tecido de ambições, de interesses, de vícios, de virtudes, de prazeres, de soffrimentos, de trabalho, de inquietação moral. Não se póde exigir que um escriptor, mudando de sangue e de nervos, annulle a influencia do meio em que vive, e narre coisas que nunca vio, costumes que nunca observou, paixões que não póde comprehender. Tal escriptor do Maranhão, do Ceará, ou de Minas, como Coelho Netto, Domingos Olympio ou Affonso Arinos, vos dará um romance em que a vida "vaqueana" do sertão maranhense se espelhe, ou onde o Ceará palpite, com as suas seccas e os seus martyrios, ou onde se fixem a bravura, as superstições, a simplicidade da gente mineira. Que vos hade dar um escriptor do Rio de Janeiro, senão a vida da rua do Ouvidor, do Theatro Lyrico, e de Botafogo?

Mas, si esse escriptor tem talento original e potente, os seus romances, como os de Machado de Assis, desvendarão na vida cosmopolita da cidade aspectos materiais e moraes que ninguém descortinaria na vida de Roma, de Lisboa ou de Paris. O amor é um só, uma só é a tolice humana, e as ruas, as casas e as almas têm afinal a mesma natureza em todas as cidades do mundo. Com os mesmos scenarios, porém, com os mesmos personagens, e com as mesmas paixões, fazem-se cem mil dramas diversos.

"A literatura de Machado de Assis realisa o milagre de crear, no Rio de Janeiro, conflictos moraes, "estados de alma", aspectos sociaes absolutamente ineditos. E isso prova mais uma vez que a mesma paixão é sentida por cem homens, de cem formas differentes, - porque cada homem traz dentro de si uma humanidade própria, que nunca é perfeitamente egual à humanidade dos outros...

$-B$. 


\section{Sobre o autor}

\section{José Raimundo Maia Neto (UFMG/CNPq)}

Professor Titular do Departamento de Filosofia da Universidade Federal de Minas Gerais (UFMG). Doutor em Filosofia pela Washington University in Saint Louis.

Recebido em: 07/07/2020.

Received: 07/07/2020.

Aprovado em: 07/09/2020.

Approved: 07/09/2020. 